\title{
Dexamethasone suppresses the growth of human non-small cell lung cancer via inducing estrogen sulfotransferase and inactivating estrogen
}

\author{
Li-jie WANG ${ }^{2}$, Jian $\mathrm{LI}^{2}$, Fang-ran $\mathrm{HAO}^{2}$, Yin YUAN² , Jing-yun $\mathrm{LI}^{2}$, Wei $\mathrm{LU}^{1,2}$, Tian-yan ZHOU ${ }^{1,2, *}$
}

${ }^{1}$ State Key Laboratory of Natural and Biomimetic Drugs, Peking University, Beijing 100191, China; ${ }^{2}$ Department of Pharmaceutics, School of Pharmaceutical Sciences, Peking University, Beijing 100191, China

Aim: Dexamethasone (DEX) is a widely used synthetic glucocorticoid, which has shown anti-cancer efficacy and anti-estrogenic activity. In this study we explored the possibility that DEX might be used as an endocrine therapeutic agent to treat human non-small cell lung cancer (NSCLC).

Methods: The viability and proliferation of human NSCLC cell lines A549 and H1299 were assessed in vitro. Anti-tumor action was also evaluated in $\mathrm{A} 549$ xenograft nude mice treated with DEX ( 2 or $4 \mathrm{mg} \cdot \mathrm{kg}^{-1} \cdot \mathrm{d}^{-1}$, ig) or the positive control tamoxifen $\left(50 \mathrm{mg} \cdot \mathrm{kg}^{-1} \cdot \mathrm{d}^{-1}\right.$, ig) for $32 \mathrm{~d}$. The expression of estrogen sulfotransferase (EST) in tumor cells and tissues was examined. The intratumoral estrogen levels and uterine estrogen responses were measured.

Results: DEX displayed mild cytotoxicity to the NSCLC cells $\left(\mathrm{IC}_{50}>500 \mu \mathrm{mol} / \mathrm{L}\right)$ compared to tamoxifen $\left(\mathrm{IC}_{50}<50 \mu \mathrm{mol} / \mathrm{L}\right)$, but it was able to inhibit the cell proliferation at low micromolar ranges. Furthermore, DEX $(0.1-10 \mu \mathrm{mol} / \mathrm{L})$ dose-dependently up-regulated EST expression in the cells, and inhibited the cell migration in vitro. Triclosan, a sulfation inhibitor, was able to diminish DEX-caused inhibition on the cell viability. In A549 xenograft nude mice, DEX or tamoxifen administration remarkably suppressed the tumor growth. Moreover, DEX administration dose-dependently increased EST expression in tumor tissues, and reduced intratumoral estrogen levels as well as the volumes and weights of uterine.

Conclusion: DEX suppresses the growth of A549 xenograft tumors via inducing EST and decreasing estradiol levels in tumor tissues, suggesting that DEX may be used as anti-estrogenic agent for the treatment of NSCLC.

Keywords: dexamethasone; tamoxifen; triclosan; estrogen sulfotransferase; non-small cell lung cancer; A549 xenograft nude mice; anticancer agent

Acta Pharmacologica Sinica (2016) 37: 845-856; doi: 10.1038/aps.2016.39; published online 2 May 2016

\section{Introduction}

Lung cancer is currently the leading cause of cancer-related death in both male and female patients worldwide. The 5 -year survival for all lung cancer patients is a dismal $15 \%{ }^{[1]}$. Therefore, new therapeutic options are urgently needed. Emerging evidence from numerous studies has suggested that the estrogen signaling pathway plays an important role in the genesis and progression of non-small cell lung cancer $(\mathrm{NSCLC})^{[2-5]}$. Estrogens are pivotal sex hormones that are essential for mammalian reproduction. However, estrogens, mainly $17 \beta$-estradiol (E2), have been implicated in lung can-

\footnotetext{
* To whom correspondence should be addressed.

E-mail tianyanzhou@bjmu.edu.cn

Received 2015-09-21 Accepted 2016-02-17
}

cer carcinogenesis ${ }^{[6]}$. Moreover, estradiol concentrations are significantly higher in lung carcinomas than in normal lung tissue ${ }^{[3]}$. Previous studies have revealed that estrogen adversely affects the prognosis of patients with NSCLC ${ }^{[7]}$. Cellular responses to estrogen are generally mediated by the estrogen receptors (ERs) ERa and ER $\beta$, which are encoded by distinct genes and have different tissue distributions. It has become apparent that ER $\beta$ is the predominant ER in most lung cancers and normal lung tissue ${ }^{[4]}$. Accordingly, blockage of intratumoral estrogen signaling appears to be a novel therapeutic approach for treating lung cancer patients with relatively modest toxicity. For example, both ER antagonists [such as tamoxifen (TAM) and fulvestrant $]^{[8,9]}$ and an aromatase inhibitor, anastrozole ${ }^{[10]}$, have been employed to suppress the growth of lung cancer cells. 
The cellular levels of estrogen are the result of a balance between (1) estrogen's synthesis by the sulfatase pathway and the aromatase pathway and (2) its transformation via sulfotransferase (SULT) ${ }^{[11]}$. SULT-mediated sulfation is an important metabolic deactivation pathway for estrogens, as estrogen sulfates cannot bind to and activate estrogen receptors and therefore do not have estrogenic activities ${ }^{[12]}$. Several SULT isoforms catalyze the sulfation of estrogen, including SULT 1A1, SULT 2A1, SULT 1A3, SULT 2B1 and SULT 1E1 $1^{[11,13]}$. Among these isoforms, SULT 1E1 (estrogen sulfotransferase, EST) is the most important SULT isoform responsible for estrogen sulfation under physiological conditions owing to its high affinity for nanomolar concentrations of estrogen ${ }^{[11,14,15]}$. Consequently, another strategy to decrease the active estrogen level is by regulating the in situ estrogen-metabolizing enzyme, EST. In fact, targeted activation of EST using genetic methods has been shown to be successful in the treatment of estrogen-dependent cancers ${ }^{[15-17]}$. However, few studies have investigated endocrine therapy for lung cancer via the upregulation of EST.

Glucocorticoids are involved in various cellular, molecular, and physiological networks in organisms and are commonly used to treat autoimmune disorders. They are also used to treat inflammation, pain, and electrolyte imbalance; to enhance the anti-tumor effect of drugs in chemotherapy; and to prevent nausea, emesis, and side effects caused by cytotoxic agents ${ }^{[18,19]}$. DEX, one of the most widely used synthetic glucocorticoids, has shown promising anti-cancer efficacy in several solid tumors, such as prostate cancer and Lewis lung cancer. DEX exhibited effective tumor growth inhibition, which was associated with down-regulation of JAK3/STAT, hypoxia inducible factor 1a, vascular endothelial growth factor and IL-6 ${ }^{[20-22]}$. Additionally, glucocorticoids inhibited estrogen responses in the rat uterus ${ }^{[23]}$. DEX blocked the stimulatory effect of estrogen on MCF-7 cell proliferation ${ }^{[24]}$ and inhibited estrogen-dependent breast cancer growth in a MCF-7 xenograft nude mouse model ${ }^{[16]}$. These findings indicated that DEX has anti-estrogenic functions and may serve as a potential anti-cancer agent in both preclinical and clinical studies. To the best of our knowledge, few studies have reported that DEX may be used as an endocrine therapeutic agent to treat NSCLC. However, the beneficial effects of DEX treatment may be limited by its accompanying side effects, including suppression of the immune system, hyperglycemia, psychosis, avascular necrosis, and the most important side effect, osteoporosis $^{[25,26]}$. This limitation underlines the importance of preclinical or clinical trials that minimize the side effects and allow new therapeutic regimens to be tested.

In the present study, we speculated that DEX could induce the expression of EST, which in turn would down-regulate the active estrogen level and exert an anti-tumor effect on NSCLC in cell culture and in vivo. Therefore, the purpose of this study was to investigate the effects of DEX on NSCLC growth in vitro and in vivo, as well as its underlying anti-estrogenic mechanisms.

\section{Materials and methods Drugs and chemicals}

DEX and TAM were purchased from Sigma-Aldrich Co (Milwaukee, WI, USA) and Cayman Chemical Co (Michigan, USA), respectively. Gemcitabine (GEM) was purchased from Dalian Meilun Biology Technology Co, Ltd (Dalian, China). RPMI-1640 medium was obtained from Macgene Biotech Co, Ltd (Beijing, China), and fetal bovine serum (FBS) was purchased from Gibco (Grand Island, USA). 17 $\beta$-Estradiol (E2) was purchased from Alfa Aesar (Waltham, MA, USA). Triclosan was purchased from Merck (Darmstadt, Germany).

\section{Cell culture}

Human NSCLC cell lines A549 and H1299 were obtained from the Institute of Materia Medica, Academy of Medical Sciences, China. The cells were cultured in RPMI-1640 medium supplemented with $10 \% \mathrm{FBS}$ at $37^{\circ} \mathrm{C}$ in a $5 \% \mathrm{CO}_{2}$ atmosphere.

\section{Cell viability assay}

A sulforhodamine B (SRB) assay ${ }^{[27]}$ was performed to examine cell viability. Briefly, A549 and H1299 cells were seeded in 96-well plates in normal growth medium at a density of 7500 and 5000 cells/well, respectively and settled overnight. The cells were then treated with a range of concentrations of DEX or TAM. After treatment for $48 \mathrm{~h}$, cells were fixed in situ with cold $10 \%(w / v)$ trichloroacetic acid (TCA). The plates were washed with water, stained with $0.4 \%$ SRB $(w / v$, dissolved in $1 \%$ acetic acid), and washed with $1 \%$ acetic acid. The proteinbound dye was subsequently dissolved in $10 \mathrm{mmol} / \mathrm{L}$ Tris. Absorbance values at $540 \mathrm{~nm}$ were recorded using a colorimetric plate reader (Bio-Rad, USA). The percent cell survival was calculated as follows: Percent cell survival=Mean $O D_{\text {treat }} /$ Mean $O D_{\text {control }} \times 100 \%$.

\section{Cell proliferation assay}

Cell proliferation was assessed using a colorimetric ELISA kit to quantify BrdU incorporation during DNA synthesis (Abcam, ab126556, USA). A549 and H1299 cells were seeded in 96-well plates overnight in culture medium. After $24 \mathrm{~h}$, the cells were treated with various concentrations of DEX $(0.1,1$, and $10 \mu \mathrm{mol} / \mathrm{L}$ ) for $48 \mathrm{~h}$. BrdU was added to the cells for $20 \mathrm{~h}$, followed by a series of procedures according to the manufacturer's protocol.

\section{Sulforhodamine B assay on the anti-estrogenic activity of DEX}

Cell viability was determined using the SRB assay. To assess the anti-estrogenic activity of DEX, the effects of E2 on the viability of A549 and H1299 cells were first evaluated. Cells were cultured in phenol-red-free and hormone-free RPMI-1640 with E2 (dissolved in DMSO) at concentrations of 0.0001, 0.01, 1 and $100 \mathrm{nmol} / \mathrm{L}$. The percentage of cell survival=Mean $O D_{\mathrm{E} 2} /$ Mean $O D_{\text {control }} \times 100 \%$. Cells were then cultured in RPMI- 1640 medium mixed with $1 \mathrm{nmol} / \mathrm{L}$ E2, and various concentrations of DEX or TAM were added. The corresponding survival rates of the cells were calculated ${ }^{[15,28]}$. 
Sulforhodamine B assay on the sulfation-inhibitory effects of triclosan

The SRB assay was further performed to investigate the effects of triclosan, an inhibitor of sulfation ${ }^{[29]}$, on the survival rate of A549 and H1299 cells exposed to DEX. When testing triclosan antagonism on DEX, cells were cultured in phenol-red-free and hormone-free medium with an optimized concentration of E2 (1 nmol/L), except cells in the control group. A549 and H1299 cells were incubated with DEX $(800 \mu \mathrm{mol} / \mathrm{L}$, diluted in DMSO) and $1 \mathrm{nmol} / \mathrm{L} \mathrm{E} 2$ in combination with different concentrations of triclosan $(0,0.1,0.5$ and $1 \mu \mathrm{mol} / \mathrm{L}$, diluted in DMSO). Then, the cell survival rates were determined using the formula described above $\mathrm{e}^{[15,27]}$.

\section{Animals}

Female nu/nu nude mice (4-5 weeks old, 18-22 g) were obtained from Beijing Vital Laboratory Animal Technology (Beijing, China). Animal procedures were approved by the Department of Laboratory Animal Science of Peking University Health Science Center (Beijing, China). The use of mice in our study complied with the Code of Ethics of the World Medical Association. The mice were housed under standard temperature $\left(22-24^{\circ} \mathrm{C}\right)$, humidity $(50 \%-60 \%)$ and light $(12 \mathrm{~h}$ light/12 h dark cycle) conditions with free access to food and water before being used in this study. This research adhered to the "Principles of Laboratory Animal Care" (NIH publication \#85-23, revised in 1985).

\section{Tumor xenograft model}

A549 cells $\left(1 \times 10^{7}\right.$ cells, suspended in $200 \mu \mathrm{L}$ of PBS) were inoculated subcutaneously into the right flank of nude mice. At approximately d 7, animals were grouped according to tumor volume, so that all groups had similar starting mean tumor volumes of approximately $100 \mathrm{~mm}^{3}$. The tumor diameter was measured with vernier calipers, and tumor volume was calculated by the following formula: tumor volume $\left(\mathrm{mm}^{3}\right)=0.5 \times \mathrm{A}(\mathrm{mm}) \times \mathrm{B}(\mathrm{mm})^{2}$, where $\mathrm{A}$ is the larger diameter, and $\mathrm{B}$ is the smaller diameter.

\section{Tumor growth inhibition assay}

DEX and TAM were dissolved in 10\% hydroxypropyl- $\beta$ cyclodextrin aqueous solution and 1,2-propanediol, respectively. DEX and TAM were administered by intragastric gavage every day. GEM was dissolved in a $0.9 \%$ sodium chloride solution and injected intravenously via a tail vein every $3 \mathrm{~d}$. After being randomly divided into different groups with five mice per group, xenograft mice were treated with vehicle solution (as a blank control), TAM (50 mg/kg), GEM (20 $\mathrm{mg} / \mathrm{kg})$ and $\operatorname{DEX}(2,4 \mathrm{mg} / \mathrm{kg})$. Tumor measurements were taken every two days. After $32 \mathrm{~d}$ of treatment, the mice were euthanized by cervical displacement. All tumors and tissues were harvested after the final treatment for later assessment.

\section{Cytosol preparation and Western blot analysis}

For the in vitro experiments, A549 and H1299 cells were harvested after treatment with DEX for $5 \mathrm{~d}$. The cells were washed with PBS followed by incubation with RIPA lysis buffer (containing $1 \mathrm{mmol} / \mathrm{L} \mathrm{PMSF}$ ) for $30 \mathrm{~min}$. After centrifugation at $14000 \times g$ for $1 \mathrm{~h}$ at $4{ }^{\circ} \mathrm{C}$, the supernatant was collected as the cell cytosol. For the in vivo experiments, three tumors from each group were randomly chosen, and cytosol samples from the tumors were prepared as previously described ${ }^{[30]}$.

The protein concentration was determined using a BCA protein assay, and Western blot analysis was performed as described in a previous study ${ }^{[31]}$. Equal amounts $(10 \mu \mathrm{g}$ for $\beta$-actin and $30 \mu \mathrm{g}$ for EST) of total protein were separated by SDS $10 \%-w / v$ polyacrylamide gel electrophoresis and transferred to PVDF membranes. Then, membranes were blocked with 5\% BSA for $2 \mathrm{~h}$ and incubated with the following antibodies for 1.5 h: anti-SULT 1E1 (1:500; Santa Cruz, USA) and anti- $\beta$-actin (1:1000; CST 4970, USA). Next, the membranes were incubated with HRP-conjugated anti-mouse IgG (1:5000; Abgent, CA, USA) and HRP-conjugated anti-rabbit IgG (1:6000; CST 7074, USA) for $2 \mathrm{~h}$. The immune complex on the membrane was developed by ECL and detected by a ChemiDoc XRS system. Finally, the protein bands were quantified by densitometry with Image Lab 5.2.1 software (Bio-Rad, USA) and normalized to $\beta$-actin.

\section{RNA extraction and real-time PCR}

Total RNA was isolated from cultured cells or cytosol of the tumors using an RNA isolation kit (Takara, Japan) and then reverse transcribed using TaqMan reverse transcription reagents according to the manufacturer's protocol. The concentration and purity of the extracted RNA were assessed by measuring the 260/280 absorption ratio using a spectrophotometer. Real-time PCR was conducted to determine the relative quantity using the comparative $C_{T}$ method $\left(2^{-\Delta \Delta C T}\right)$. Realtime PCR for EST and $\beta$-actin was performed on the MyiQ5 Real-time PCR Detection System (Bio-Rad) using SYBR Premix Ex Taq $^{\mathrm{TM}}$ (Takara). The primer sequences used here were reported previously ${ }^{[15]}$ : forward primer, 5'-CGCGAGAAGATGACCCAGAT-3' and reverse primer, 5'-TCACCGGAGTCCATCACGAT-3' ( $\beta$-actin, Gene ID: 60); forward primer, 5'-ATCTTGTCATTGCCACCTAC-3' and reverse primer, 5'-TGGCAAATGAGTCTTCAC-3' (EST, Gene ID: 6783). All the primers were purchased from AuGCT DNA-SYN Biotechnology Co, Ltd (Beijing, China). Samples were run in triplicate under the following conditions: initial denaturation for $30 \mathrm{~s}$ at $95^{\circ} \mathrm{C}$, followed by 45 continuous cycles of $15 \mathrm{~s}$ at $95^{\circ} \mathrm{C}, 30 \mathrm{~s}$ at $60^{\circ} \mathrm{C}$ and $33 \mathrm{~s}$ at $72^{\circ} \mathrm{C}$. The gene expression levels in each sample were normalized to $\beta$-actin.

\section{Measurement of tumor E2 level}

Tumor-bearing mice were treated with DEX for $32 \mathrm{~d}$, and the cytosol of the tumors was prepared as previously described ${ }^{[15]}$. The concentrations of E2 in A549 xenograft tumors were measured using an ELISA kit from Puli Zhicheng Biotechnology Co, Ltd (Beijing, China) according to the manufacturer's instructions. 


\section{Uterotropic bioassay}

Tumor-bearing mice were subjected to daily injections of vehicle or DEX fot $32 \mathrm{~d}$ as previously described. Mice were then euthanized after the last treatment. Collected uteri were photographed and weighed as previously reported ${ }^{[16]}$. Uteri weights were normalized to corresponding body weights.

\section{Wound healing assay}

Cells were seeded into 6-well plates and settled overnight. A linear wound was generated with a $200 \mu \mathrm{L}$ pipette tip, and the monolayer was washed with PBS buffer. The wounded monolayer of cells was allowed to migrate for $24 \mathrm{~h}$ in the presence of $0.1,1$, or $10 \mu \mathrm{mol} / \mathrm{L}$ DEX in combination with mitomycin $\mathrm{C}(5 \mu \mathrm{mol} / \mathrm{L})^{[32]}$. Images of cell movement were captured and analyzed with Image J 1.48 software (National Institutes of Health, USA).

\section{Hematoxylin and eosin (H\&E) staining}

Harvested tumors (including from the control, TAM, GEM and $4 \mathrm{mg} / \mathrm{kg}$ DEX groups) from A549 xenograft mice were fixed with $10 \%$ formalin, embedded in paraffin wax, sliced and mounted on slides. Sections were stained with hematoxylin and eosin (H\&E) to evaluate morphological changes.

\section{Blood test}

Blood samples were collected from the postorbital venous plexus using a microcapillary tube after $32 \mathrm{~d}$ of DEX treatment in tumor-bearing mice. Blood samples $(20 \mu \mathrm{L})$ were added to $5 \mathrm{~mL}$ of diluent solution and mixed thoroughly. Hemograms were determined using a MEK-6318K Hematology Analyzer (Nihon Kohden, Japan).

\section{Statistical analysis}

When applicable, the results are expressed as the mean \pm SD. One-way analysis of variance (ANOVA) was applied to determine the significance among groups, followed by post hoc tests with Bonferroni's correction. $P<0.05$ was considered statistically significant. Statistical analyses were performed using GraphPad Prism 5.0 software (GraphPad Software, Inc, USA).

\section{Results \\ DEX had minimal cytotoxic effects but inhibited the proliferation of NSCLC cells}

The $\mathrm{IC}_{50}$ values of DEX in A549 and H1299 cells were greater than $500 \mu \mathrm{mol} / \mathrm{L}$, whereas those of TAM were less than 50 $\mu \mathrm{mol} / \mathrm{L}$ (Figure 1A), indicating that, unlike cytotoxic agents, DEX could not destroy NSCLC cells directly. The proliferation of A549 and H1299 cells was assessed in the presence or absence of DEX using a BrdU ELISA kit. Figure 1B showed that a low dose of $\operatorname{DEX}(0.1 \mu \mathrm{mol} / \mathrm{L}$ and $1 \mu \mathrm{mol} / \mathrm{L})$ had no influence on A549 cell proliferation, whereas $10 \mu \mathrm{mol} / \mathrm{L}$ DEX reduced the relative proliferation ratio of A549 cells to $89.21 \%$. With DEX treatment, the relative rates of proliferation for H1299 cells were $63.92 \%(0.1 \mu \mathrm{mol} / \mathrm{L}), 50.08 \%(1 \mu \mathrm{mol} / \mathrm{L})$ and $48.63 \%(10 \mu \mathrm{mol} / \mathrm{L})$. These results indicated that although DEX was able to inhibit the proliferation of both A549 and
H1299 cells, the effect of DEX was much stronger on H1299 cells than on A549 cells.

\section{DEX significantly inhibited the tumor growth of an A549 xenograft}

To assess whether DEX has an anti-cancer effect on NSCLCs in vivo, an A549 xenograft tumor model was used. Animals were given oral doses of DEX at 2 or $4 \mathrm{mg} / \mathrm{kg}$ once daily. Compared with the control treatment, DEX treatment strikingly inhibited tumor growth (Figure 1C). Notably, the inhibition of tumor growth induced by the low dose of DEX (2 mg/ kg) was $73.4 \%$, which was greater than that induced by GEM (inhibitory ratio was $52.6 \%$ ) and equivalent to that of TAM (50 mg/kg), which was $70.8 \%$. Clearly, $4 \mathrm{mg} / \mathrm{kg}$ DEX exerted the most potent anti-tumor efficacy with an inhibitory ratio near $92.5 \%$.

\section{DEX had anti-estrogenic activity in vitro}

Based on the measurement of cellular protein content, the SRB assay is a widely used and efficient method for testing cell viability and chemosensitivity ${ }^{[33]}$. Herein, the SRB assay was used to evaluate the growth inhibitory activity of DEX and TAM in NSCLC cells. First, we examined whether E2 could play a role in NSCLC cell survival. The SRB assay revealed that the highest stimulation of cell survival was observed when $1 \mathrm{nmol} / \mathrm{L}$ E2 was present in the culture (Figure 2A) in both A549 and H1299 cells. Moreover, the results implied that both A549 and H1299 cells were sensitive to treatment with E2. The cell survival rates of the groups for both cell types were increased after treatment with 0.01 and $1 \mathrm{nmol} / \mathrm{L} \mathrm{E} 2$, while $100 \mathrm{nmol} / \mathrm{L}$ E2 had no effect on cell growth (Figure 2A). The inhibitory effects of DEX or TAM on A549 and H1299 cells resulted when both cell lines were exposed to $1 \mathrm{nmol} / \mathrm{L}$ E2 in combination with DEX or TAM. DEX inhibited A549 and H1299 cell growth when the cells were exposed to more than $500 \mu \mathrm{mol} / \mathrm{L}$ DEX with $1 \mathrm{nmol} / \mathrm{L} \mathrm{E} 2$ incubation (Figure 2B), indicating that DEX has a certain degree of anti-estrogenic activity in NSCLC cells, although the activity of DEX in vitro is smaller than that of TAM.

\section{Triclosan antagonized the effect of DEX on the loss of cell viability}

Triclosan has been shown to interfere with estradiol sulfation by human sulfotransferases ${ }^{[15,29]}$. Thus, triclosan is an ideal inhibitor of sulfation to evaluate the role of EST in the development and progression of NSCLC. To further explore whether the sulfation of estrogen by EST is involved in DEXmediated inhibition of NSCLC cell viability, the survival rates of cells incubated with various doses of triclosan in combination with DEX $(800 \mu \mathrm{mol} / \mathrm{L})$ in phenol-red-free and hormonefree RPMI-1640 medium (containing $1 \mathrm{nmol} / \mathrm{L} \mathrm{E2)} \mathrm{were} \mathrm{mea-}$ sured using the SRB assay. In the absence of triclosan, DEX $(800 \mu \mathrm{mol} / \mathrm{L})$ alone reduced the survival rates of A549 and H1299 cells by $63.2 \%$ and $51.2 \%$, respectively (Figure $2 \mathrm{C}$ ). As expected, the effect of DEX on cell survival was significantly diminished by the addition of triclosan. The cell survival rates increased significantly compared to the cells treated with DEX only. Overall, these data suggest that triclosan can antago- 
A
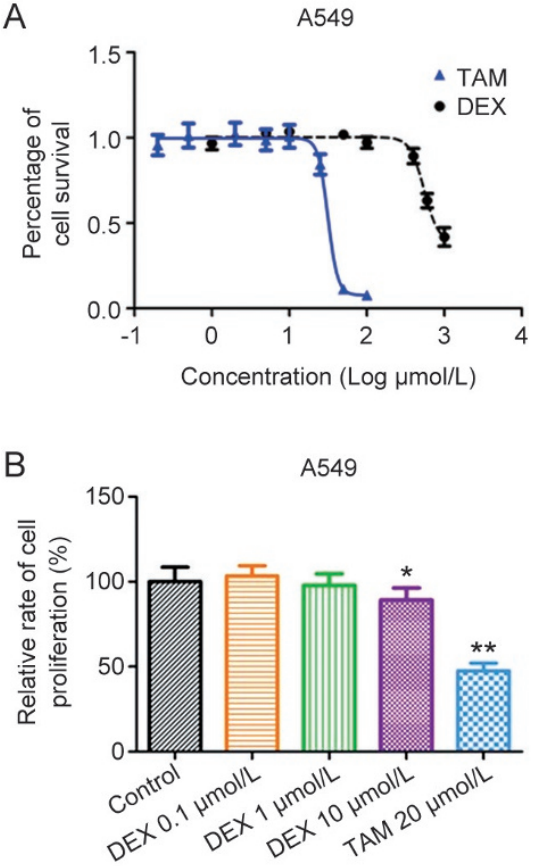

C

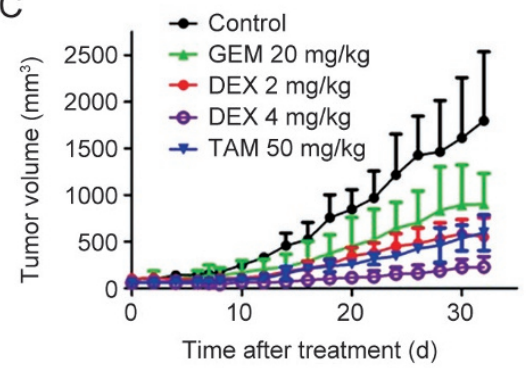

H1299

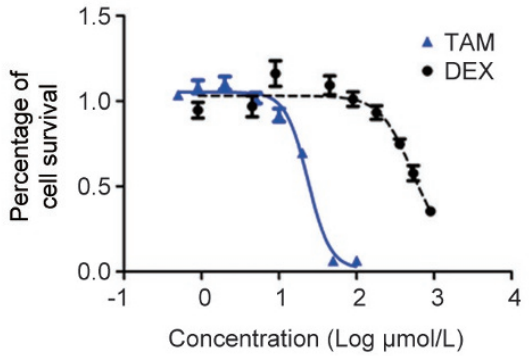

H1299
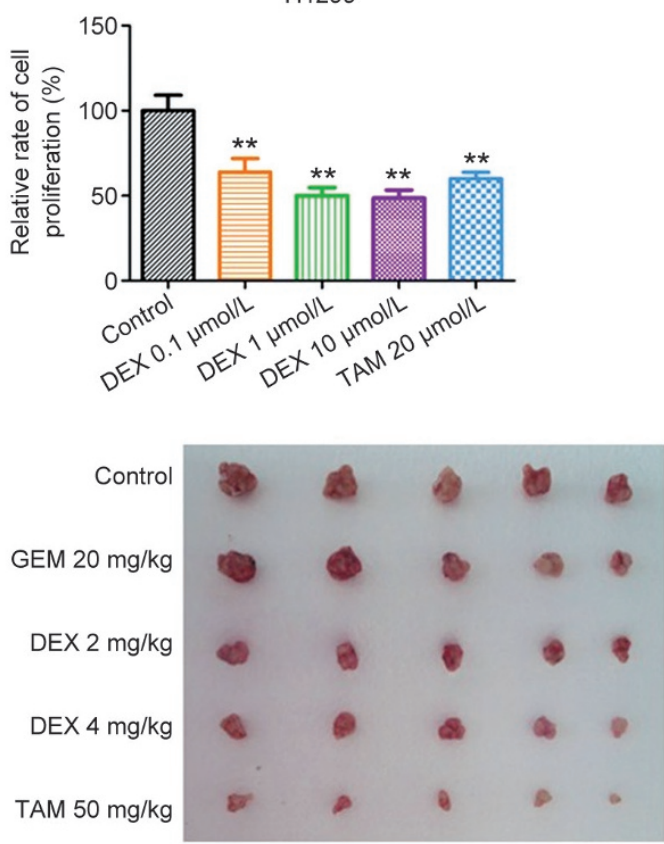

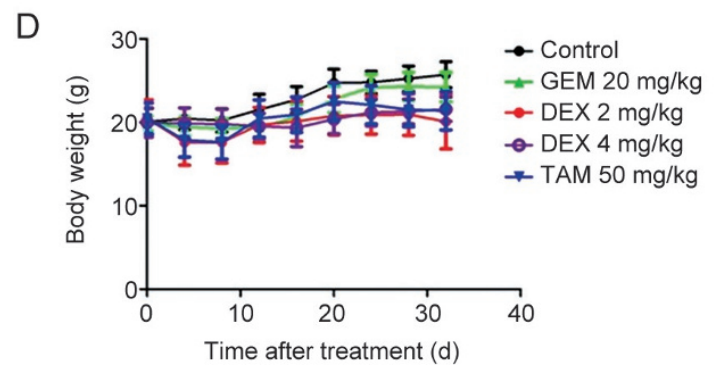

Figure 1. DEX inhibited NSCLC growth in vitro and in vivo. (A) Cell viability was evaluated using the SRB assay. A549 and $\mathrm{H} 1299$ cells were treated with DEX or TAM at the indicated concentrations for $48 \mathrm{~h}$ before analysis. The data points are the mean $\pm \mathrm{SD}(n=6)$. (B) Cell proliferation was assessed with a BrdU ELISA kit. A549 and H1299 cells were incubated with DEX or TAM for $48 \mathrm{~h}$ before analysis. The data points are the mean \pm SD ( $n=6)$. (C) Growth kinetics of A549 tumors in the presence of drug treatments. Tumors were photographed after the mice were sacrificed on d 32 . Nu/nu mice, randomly divided into various control and treatment groups (5 mice/group), were treated with HP- $\beta$-CD as a control, DEX (ig, qd), TAM (ig, qd), GEM (iv, q3d). (D) Body weights of DEX treatment groups were similar to those in the control group, indicating that DEX has low toxicity. Tumor volume was expressed as the mean $\pm S D$. HP- $\beta$-CD, hydroxypropyl- $\beta$-cyclodextrin; ig, intragastric administration; qd, every day; iv, intravenous administration; $q 3 \mathrm{~d}$, every three days. ${ }^{*} P<0.05,{ }^{* *} P<0.01$ compared with the control group.

nize DEX-mediated loss of cell viability in a dose-dependent manner.

\section{DEX induced EST in A549 and H1299 cells}

The effect of DEX on expression of human EST protein was further investigated in A549 and H1299 cells. Western blot results revealed that the protein expression of EST increased significantly after DEX treatment (Figure 2D). Moreover, DEX treatment dramatically up-regulated EST mRNA expression in both NSCLC cell lines in a dose-dependent manner (Figure 

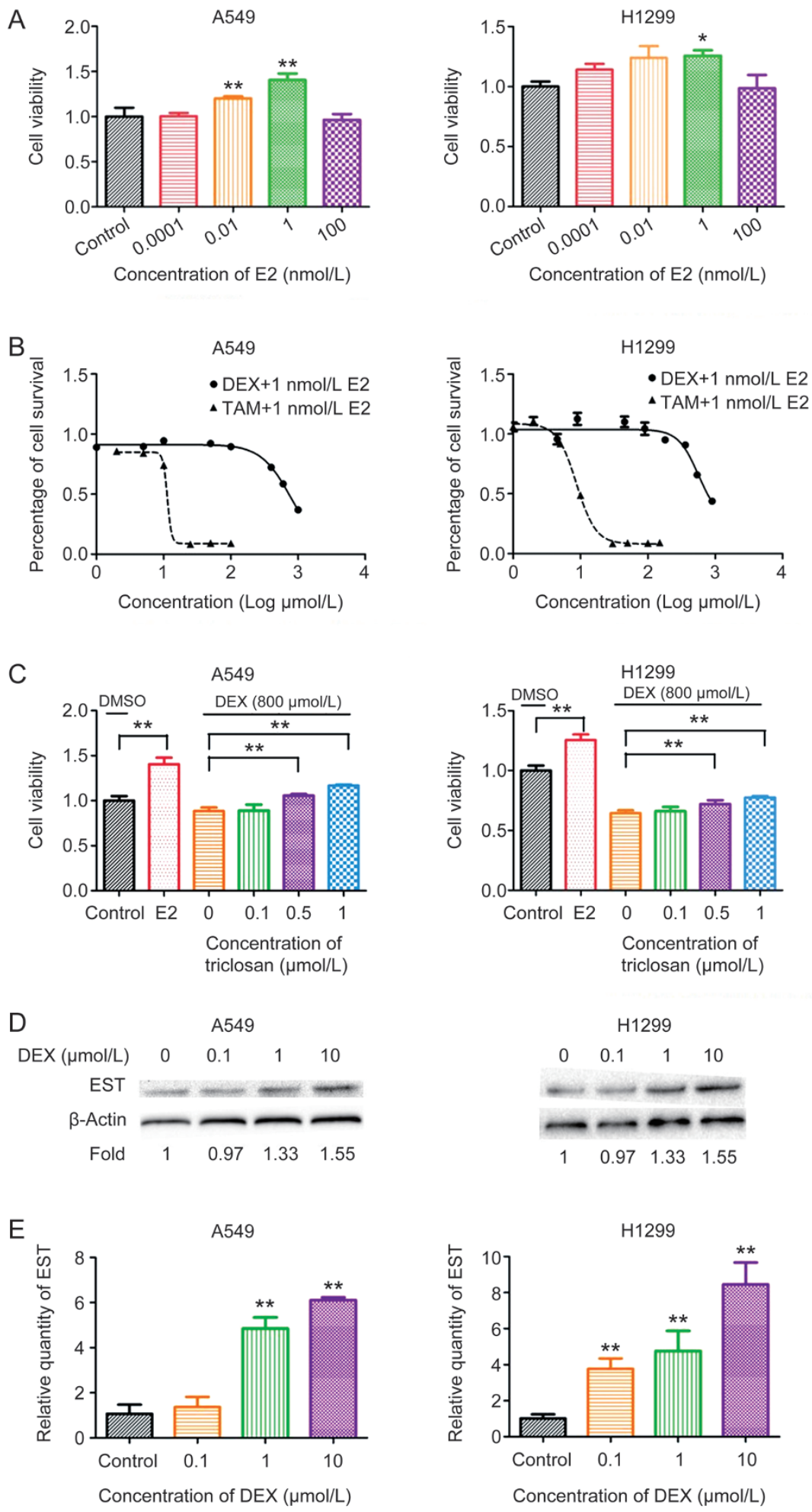

Figure 2. DEX has anti-estrogenic activity in vitro. (A) The effect of E2 on the survival of A549 and H1299 cells. (B) Cell viability of A549 and H1299 cells treated with DEX or TAM and $1 \mathrm{nmol} / \mathrm{L}$ E2 as determined by the loss of cell viability. (C) The cell viability of A549 and H1299 cells treated with $800 \mu \mathrm{mol} / \mathrm{L} \mathrm{DEX}$ and $1 \mathrm{nmol} / \mathrm{L}$ E2 was counteracted by various concentrations of triclosan (an inhibitor of sulfation), indicating that the sulfation of estrogens by EST is potentially involved in the anti-cancer efficacy of DEX. Cells were subjected to DMSO, E2, E2+DEX, E2+DEX+0.1 $\mu \mathrm{mol} / \mathrm{L}$ triclosan, $E 2+D E X+0.5 \mu \mathrm{mol} / \mathrm{L}$ triclosan or E2+DEX+1 $\mu \mathrm{mol} / \mathrm{L}$ triclosan. (D) The relative expression of the EST protein in A549 and $\mathrm{H} 1299 \mathrm{cells}$ after treatment with DEX for $5 \mathrm{~d}$ was up-regulated as determined by Western blot analysis. The expression of $\beta$-actin was included as a loading control. (E) DEX induced EST mRNA expression in A549 and H1299 cells. The EST levels in A549 and H1299 cells increased in a dose-dependent manner after treatment with DEX for 5 d. ${ }^{*} P<0.05,{ }^{* *} P<0.01$ vs control group unless otherwise labeled. 
2E), which was consistent with the Western blot analysis. The maximal relative induction of EST mRNA expression in both H1299 and A549 cells was greater than 6-fold.

\section{DEX induced EST and reduced the E2 level in tumors}

Consistent with the in vitro results, DEX up-regulated the protein and mRNA expression of EST in A549 xenograft tumors with increases of 2.19- and 1.83-fold at a dose of $4 \mathrm{mg} / \mathrm{kg}$, respectively, as confirmed by Western blot and real-time PCR analysis (Figure 3A and 3B). An ELISA analysis revealed that the active E2 concentrations decreased from $58.00 \mathrm{ng} / \mathrm{L}$ to $49.46 \mathrm{ng} / \mathrm{L}$ and $48.58 \mathrm{ng} / \mathrm{L}$ in $2 \mathrm{mg} / \mathrm{kg}$ and $4 \mathrm{mg} / \mathrm{kg}$ treated xenograft tumors, respectively (Figure 3C).

\section{DEX inhibited the uterine responses in vivo}

The uterus is highly responsive to estrogens and reflects the level of active E2 in the circulating system ${ }^{[34]}$. Therefore, we used uterine estrogen responses to examine the biological consequences of DEX treatment. As shown in Figure 3D, DEX dose-dependently inhibited the uterine responses, as the vol- umes and weights of uteruses were markedly decreased. After DEX treatment $(4 \mathrm{mg} / \mathrm{kg}$ ) for $32 \mathrm{~d}$, the relative weight of the uterus decreased from 2.84 (control group) to 1.80. Combined, these data suggest that the active E2 levels in both tumors and the circulation were down-regulated by DEX treatment.

\section{DEX inhibited NSCLC cell migration}

Lastly, to test whether DEX has an inhibitory effect on cell migration, cells were subjected to wound healing assays in the presence of DEX. To quantify wound healing, the wound area of vehicle-treated cells after $24 \mathrm{~h}$ was defined as $100 \%$. Mitomycin C ( $5 \mu \mathrm{mol} / \mathrm{L})$ was added to stop cell proliferation. H1299 cells showed a greater decrease in the wound area, indicating that H1299 cells possibly have a higher migratory ability than A549 cells. As shown in Figure 4, DEX inhibited cell migration in a dose-dependent manner. Up to 1.72- and 2.63fold inhibition of cell migration was observed in $10 \mu \mathrm{mol} / \mathrm{L}$ DEX-treated A549 and H1299 cells, respectively. These observations suggest that DEX treatment might reduce migration ability in NSCLC cells.
A

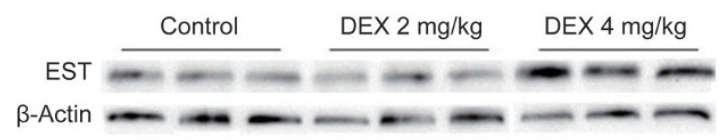

B

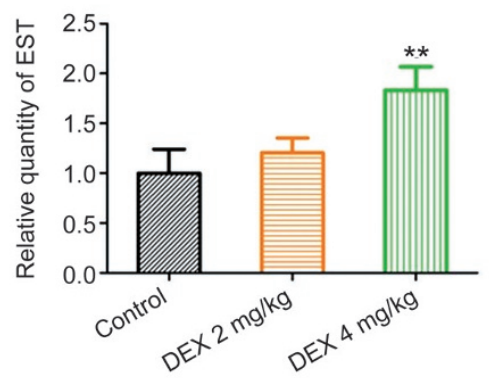

D

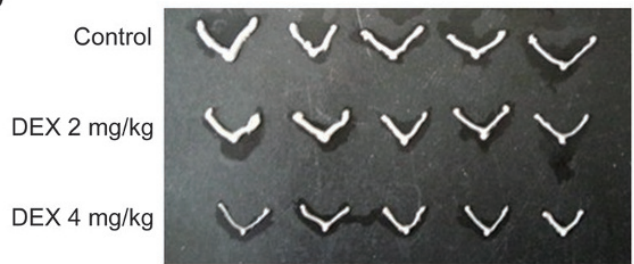

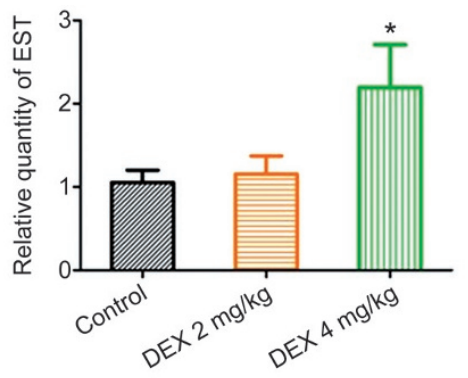
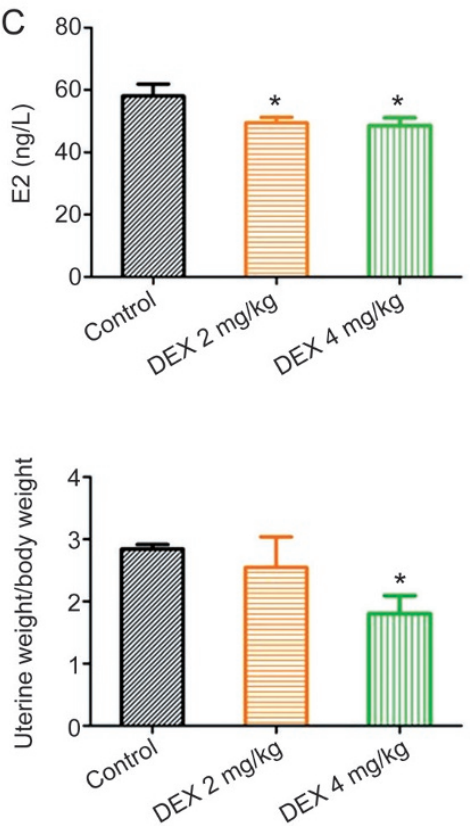

Figure 3. DEX inhibited the estrogen response in vivo. (A) Western blot results showed that DEX induced the protein expression of intratumoral EST. (B) Compared with the control group, the mRNA expression of EST in tumors was strongly induced by the administration of DEX (4 mg/kg). (C) Levels of E2 in the cytosol of the tumors from mice at the time of sacrifice (32 d post-administration). (D) Uterine from the tumor-bearing mice and their corresponding weights determined with an uterotropic bioassay. Meas \pm SD. $n=3$. ${ }^{*} P<0.05,{ }^{* *} P<0.01$ vs control. 
A
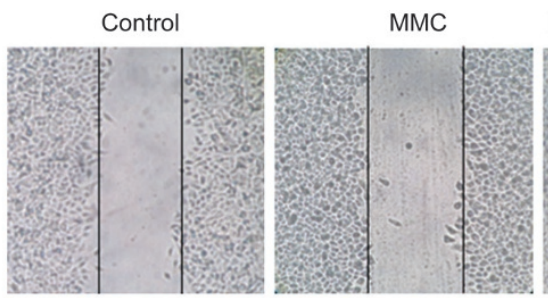
$\mathrm{MMC}+\mathrm{DEX} 0.1 \mu \mathrm{mol} / \mathrm{L}$
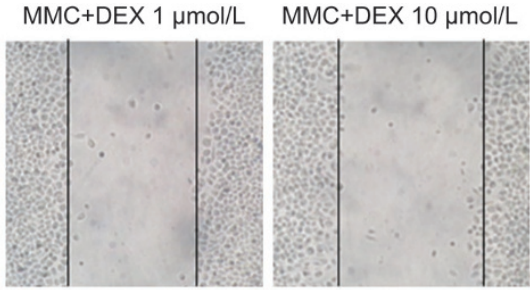

B
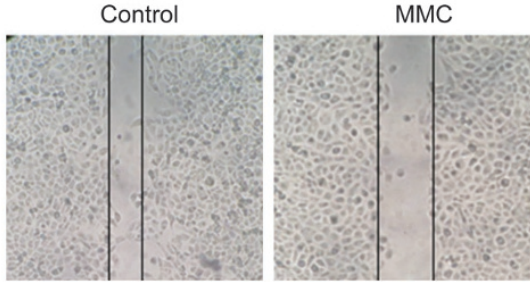

$\mathrm{MMC}+\mathrm{DEX} 0.1 \mu \mathrm{mol} / \mathrm{L}$
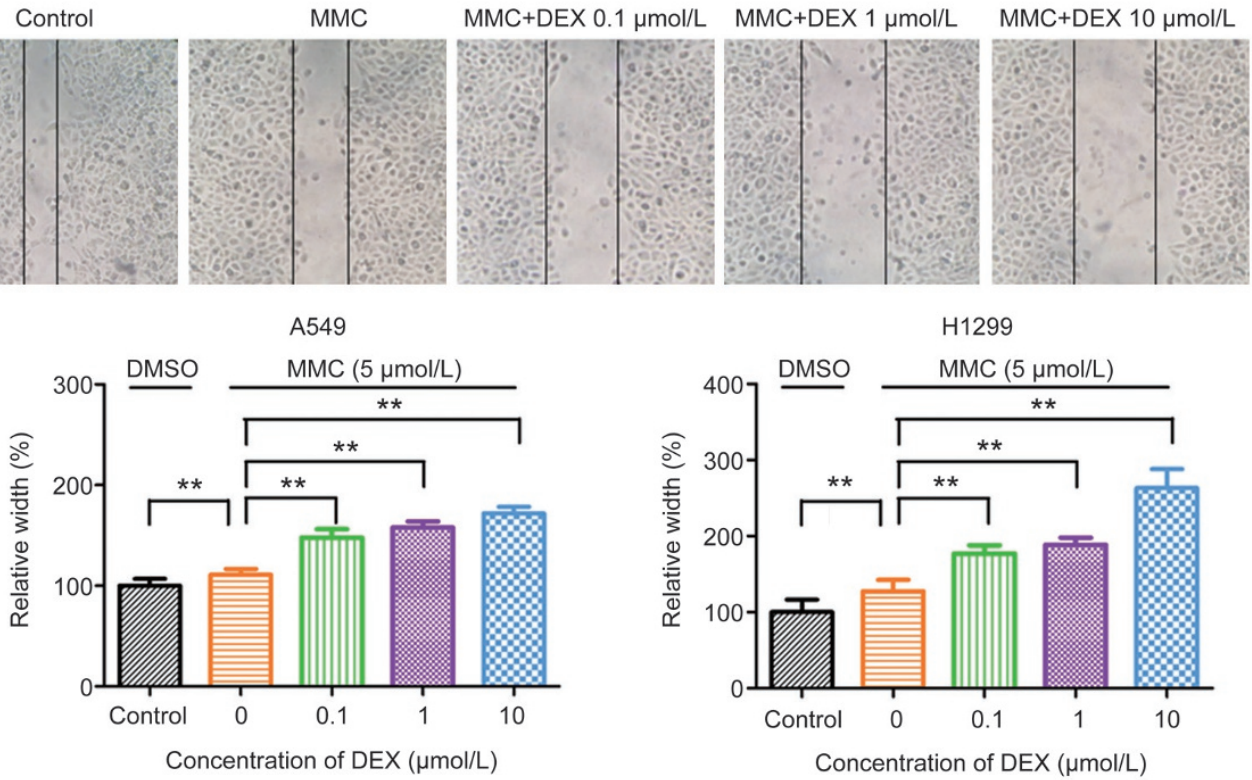

Figure 4. Wound healing assay by a single scratch of a pipette tip on adherent A549 cell (A) and H1299 cell (B) migration after exposure to 0.1 , 1 , and $10 \mu \mathrm{mol} / \mathrm{L}$ DEX or DMSO for $24 \mathrm{~h}$. Mitomycin C (MMC, $5 \mu \mathrm{mol} / \mathrm{L})$ was used to inhibit cell proliferation. The results indicated that DEX potently inhibited NSCLC cell migration.

\section{Toxicity analysis of DEX in vivo}

DEX potently suppressed tumor growth and showed little systemic toxicity as reflected by the absence of significant body weight loss in the treated animals compared with other treatment groups (Figure 1D). Additionally, there were no obvious alterations in organ tissues except for the liver in the DEX treatment groups as suggested by the results of H\&E staining (heart, lung, liver, spleen and kidney; Figure 5). Histology results showed some inflammatory cell infiltration in the DEX treatment group. Blood tests revealed no evidence of blood toxicity after treatment with DEX, except that the number of white blood cells was decreased (Figure 6).

\section{Discussion}

The anti-cancer efficacy of DEX in solid tumors has been documented in recent years ${ }^{[18,21,35,36]}$; the mechanism by which DEX suppresses tumor cell growth is still unclear. In this paper, we found that the ability of DEX to reduce the cell viability of NSCLC cells was much weaker than that of TAM. However, a $4 \mathrm{mg} / \mathrm{kg}$ dose of DEX caused significant inhibition of tumor growth compared with TAM or GEM treatment. These results supported the hypothesis that DEX could inhibit the growth of NSCLC cells. A toxicity analysis showed that DEX was well tolerated with little systemic toxicity or hematotoxicity being identified, except that some inflammatory cell infiltration was observed in the liver histology. The liver is the primary metabolic organ of DEX. A previous study demonstrated that higher doses of DEX ( 4 and $8 \mathrm{mg} / \mathrm{kg}$, ip) in rats produced fatty accumulation in the liver parenchyma, which resulted in hepatic steatosis ${ }^{[37]}$. Hence, the optimization of the dose regimen or dosage form is of high value in the clinical use of DEX. Despite side effects associated with DEX usage, the preclinical outcome was promising as xenograft tumor growth was significantly inhibited.

Estrogen is speculated to play an important part in lung cancer carcinogenesis and to adversely affect patient prognosis. As mentioned earlier, the stimulatory role of estrogens in lung cancer initiation and progression has been recognized recently ${ }^{[4-7]}$. Our in vitro results confirmed that both A549 and H1299 cells were sensitive to E2 incubation. The critical role of estrogens in lung carcinogenesis is further reinforced by the observation that anti-estrogen usage is related to decreased lung cancer mortality risk ${ }^{[38]}$. TAM, one of the most commonly used selective estrogen receptor modulators (SERMs) in estrogen receptor-positive breast cancer, competitively inhibits estrogen binding to ER and is therefore an antagonist of estro- 


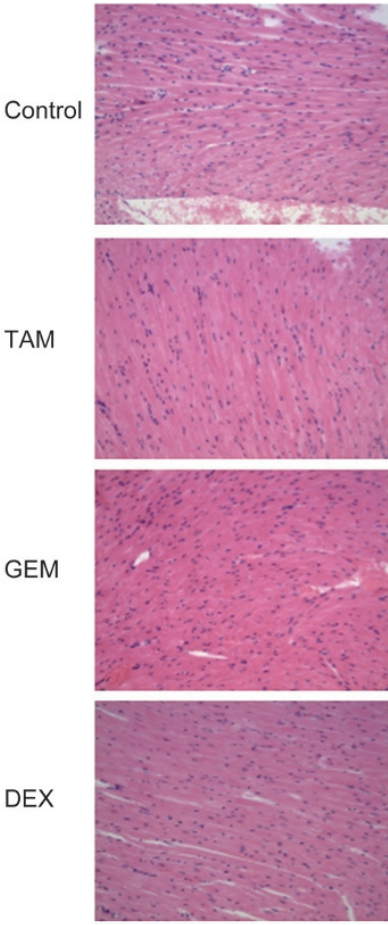

Heart
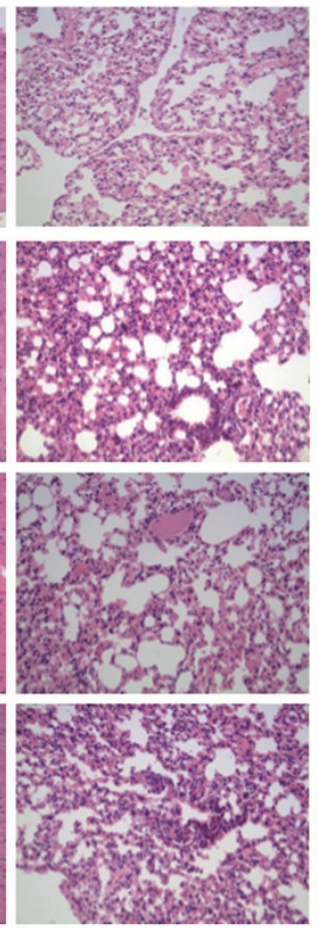

Lung
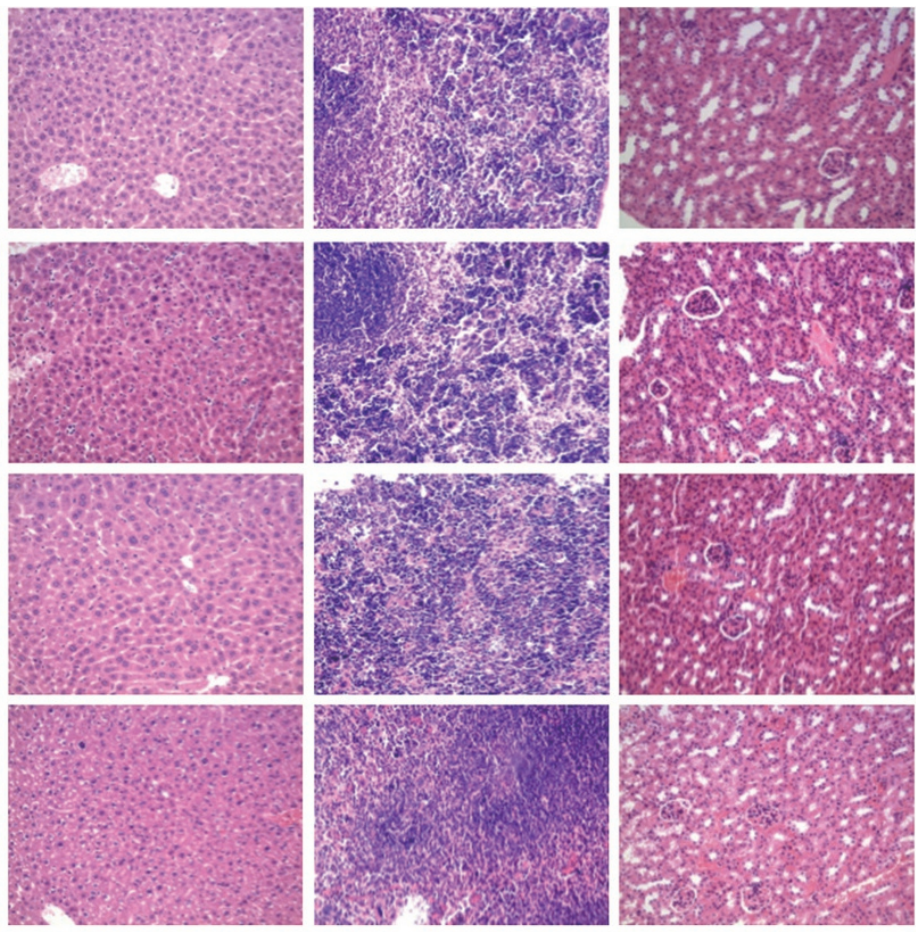

Liver

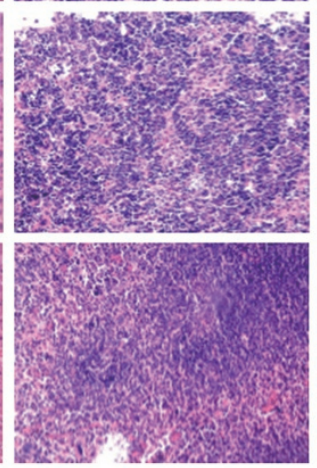

Spleen

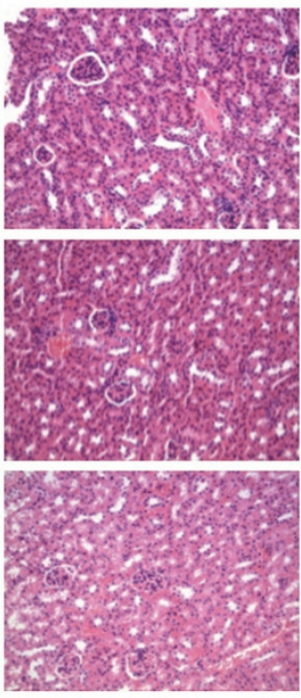

Kidney

Figure 5. H\&E staining of histologic sections of heart, lung, liver, spleen and kidney from different administration groups, ie, Control, TAM (50 mg/kg, ig), GEM (20 mg/kg, iv) and DEX (4 mg/kg, ig).

gen signaling ${ }^{[39]}$. Fulvestrant, another ER antagonist with no agonist effects, elicited significant tumor growth inhibition in an NSCLC xenograft model when it was used alone or in combination with other anti-cancer agents ${ }^{[9,40]}$. Previous studies demonstrated that TAM treatment inhibited cell survival in H520 and H1975 cells, while cotreatment with gefitinib plus TAM decreased proliferation and increased apoptosis in A549 and $\mathrm{H} 1650$ cells $^{[41,42]}$. We demonstrated that TAM has anticancer and anti-estrogenic activity in NSCLC xenograft mice for the first time. In this study, TAM exhibited significant anti-estrogen effects in A549 and H1299 cells and reduced growth in the A549 xenograft model as well. Nevertheless, DEX showed some degree of anti-estrogenic activity in vitro but resulted in a significant decrease in E2 concentration in the tumor and remarkable tumor growth delay with an inhibitory ratio up to $92.5 \%$. TAM is an antagonist of ER in breast tissue via its active metabolites (ie, 4-hydroxy tamoxifen and $\mathrm{N}$-desmethy-4-hydroxy tamoxifen ${ }^{[43]}$. The metabolites function as ER antagonists and block the ER signaling pathway in cancer cells, which does not alter estrogen levels directly. By contrast, DEX treatment induced EST expression and thereby down-regulated estrogen levels in A549 xenograft tumors. We also examined the effect of TAM on EST expression but no significant influence was observed (data no shown).

To our knowledge, no studies have assessed the intratumoral E2 concentration in NSCLC xenograft mice. In this research, we showed that after DEX treatment, the intratumoral E2 concentrations in the DEX treatment ( 2 and $4 \mathrm{mg} / \mathrm{kg}$ ) groups were $49.46 \mathrm{ng} / \mathrm{L}$ and $48.58 \mathrm{ng} / \mathrm{L}$, respectively, which was much lower than that detected in the control group (58.00 $\mathrm{ng} / \mathrm{L}$ ). Of interest, we tried to examine the E2 concentration in healthy lung tissues with the same ELISA kit, but the concentration was too low to be detected. Our results suggest that estrogens play a key role in the production and progression of NSCLC tumors. Most breast cancers are estrogendependent and require the presence of estrogens to maintain tumor growth. This fact prompted us to test intratumoral estrogen levels in breast cancer tumors. Using the xenograft model developed by our group ${ }^{[4]]}$, we found that the E2 level in MCF-7 tumors was $78.02 \mathrm{ng} / \mathrm{L}$. Although the E2 concentration in A549 tumors was lower than in breast cancer, it was still at a high level, suggesting that regulation of intratumoral E2 concentration may be an effective way to inhibit the growth of NSCLC cells in a future clinical trial.

Glucocorticoids attenuate estrogen-stimulated uterine responses ${ }^{[16,23]}$. Previous studies revealed that DEX antagonizes estrogens by activating EST in MCF-7 breast cancer ${ }^{[16]}$. Here we assume that DEX treatment may lower circulating estrogens, compromise uterine estrogen responses and inhibit NSCLC growth, all of which might be due to estrogen-related mechanisms, such as the induction of EST. Our results confirmed that DEX greatly increased the expression of EST in both A549 and H1299 cells, as well as in xenograft tumor tissues. In addition, treating A549 and H1299 cells in vitro with an estrogen sulfation inhibitor, triclosan, counteracted the cell viability loss caused by DEX. 

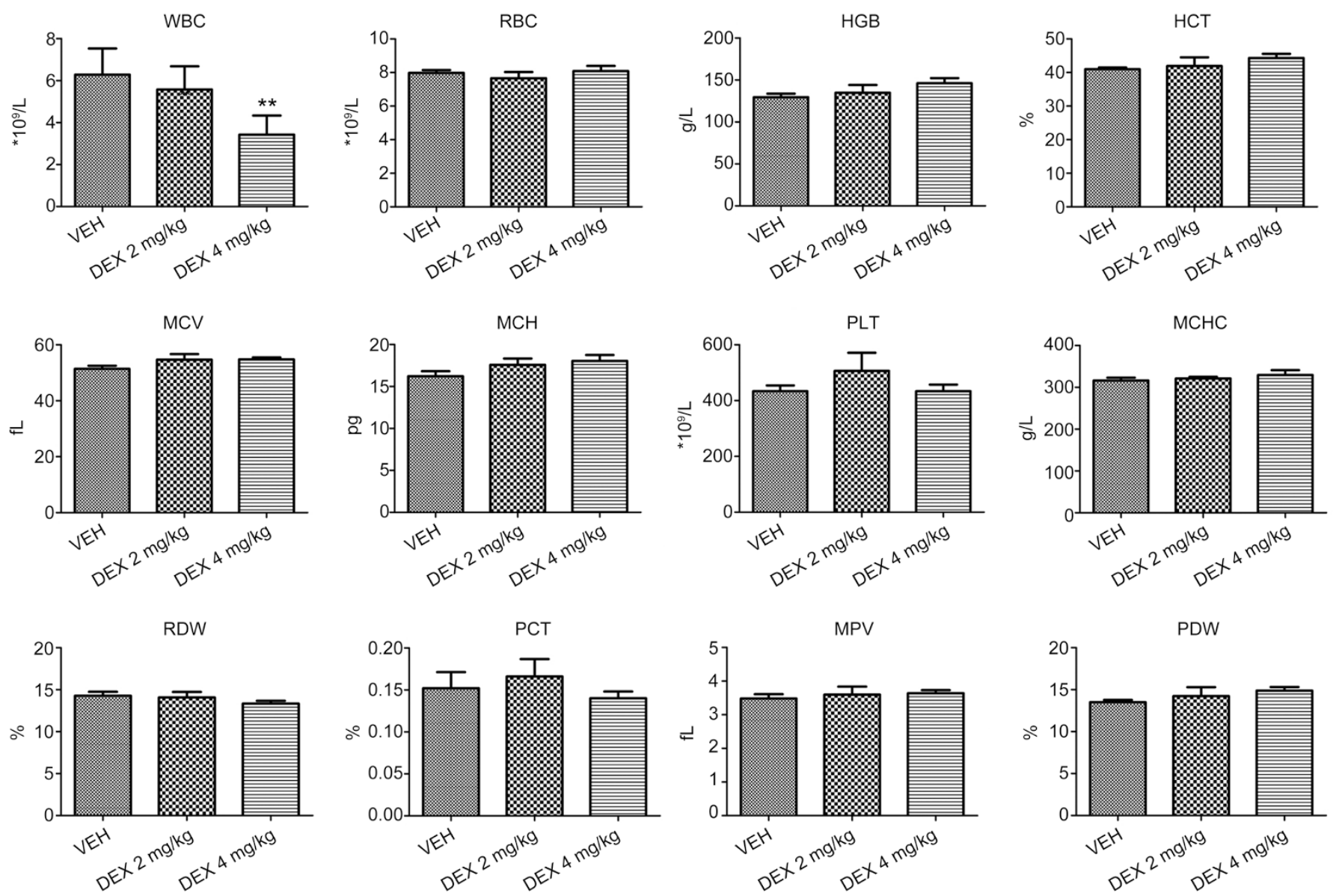

Figure 6. Hemogram analysis of blood samples on d 32 after treatment with different drugs in A549 tumor-bearing mice. ${ }^{*} P<0.05$, ${ }^{* *} P<0.01$ vs control.

This result confirmed that DEX could interfere with estrogen sulfation. BrdU proliferation results indicated that although DEX was able to inhibit the proliferation of both A549 and H1299 cells, the effect of DEX on H1299 cells was much stronger than on A549 cells. Therefore, the mild inhibition of A549 cell proliferation contributed slightly to the tumor growth suppression in the A549 xenograft model, which signified EST induction in A549 tumor inhibition. Our previous study revealed that the induction of EST and down-regulation of estrogens was involved in the anti-breast cancer activity of a dithiocarbamate derivate, TM208, which indirectly demonstrated the potential clinical use of DEX in endocrine therapy $^{[15]}$.

Our in vitro results showed that the $\mathrm{IC}_{50}$ values in both A549 and H1299 cells were more than $500 \mu \mathrm{mol} / \mathrm{L}$, and DEX showed no effect on A549 cell apoptosis in vitro (data not shown), suggesting that DEX does not directly affect the survival of A549 cells. However, the inhibition of tumor growth by DEX was much stronger than by GEM, a cytotoxic chemotherapy drug, which is widely used to treat NSCLC in the clinic. Thus, instead of eradicating tumor cells, our results indicated that DEX might exert its anti-tumor efficacy by suppressing the intratumoral estrogen signaling pathway in vivo and, hence, slow tumor progression indirectly; however, some other mechanisms (such as its anti-inflammatory, immunosuppression roles, etc ${ }^{[22,45]}$ may be involved, which needs further investigation. In fact, most of the use of DEX in patients with a solid tumor does not aim to destroy malignant cells, but rather to alleviate symptoms caused by either cytotoxic agents or the tumor, such as edema, nausea, emesis, inflammation, pain, lack of appetite, and electrolyte imbalance ${ }^{[46,47]}$. We still think that DEX exerts the above various effects in the treatment of NSCLC, but in this study, we demonstrated that DEX could be used as an endocrine drug for NSCLC therapy.

In addition, Egberts et al have demonstrated that DEX strongly inhibited the invasiveness of PDAC cells as well as the activation of NF- $\mathrm{KB}$, thus reducing tumor recurrence and metastasis after pancreatic tumor resection in SCID mice ${ }^{[48]}$. In the wound healing assay, mitomycin $\mathrm{C}$ was added to exclude the effect of proliferation on cell migration. The results revealed that DEX reduced NSCLC cell migration in a dosedependent manner (Figure 4), suggesting that DEX has great promise in cancers associated with a high tendency of invasion and metastasis. Therefore, DEX is a multiple target old drug with a new function in the treatment of NSCLC.

Taken together, the inhibition of estrogenic activity by DEX is promising for future clinical practice. Our research implied that DEX may be used as a new endocrine therapeutic drug 
with multiple functions in lung cancer treatment, and this novel application of DEX is likely to achieve a significant effective response in the clinical treatment of NSCLC.

\section{Abbreviations}

DEX, dexamethasone; NSCLC, non-small cell lung cancer; EST, estrogen sulfotransferase; E2, 17 $\beta$-estradiol; ER, estrogen receptor; TAM, tamoxifen; SULT, sulfotransferase; GEM, gemcitabine; SRB assay, sulforhodamine B assay.

\section{Acknowledgements}

This study was supported by the National Natural Science Foundation of China (Grant No 81273583 ).

\section{Author contribution}

Tian-yan ZHOU and Li-jie WANG designed the research; Lijie WANG, Jian LI, Fang-ran HAO, Yin YUAN and Jing-yun LI performed the research; Li-jie WANG, Tian-yan ZHOU and Wei LU analyzed the data; and Li-jie WANG wrote the manuscript.

\section{References}

1 Siegel R, Naishadham D, Jemal A. Cancer statistics, 2013. CA Cancer J Clin 2013; 63: 11-30.

2 Márquez-Garbán DC, Chen HW, Fishbein MC, Goodglick L, Pietras RJ. Estrogen receptor signaling pathways in human non-small cell lung cancer. Steroids 2007; 72: 135-43.

3 Marquez-Garban DC, Chen HW, Goodglick L, Fishbein MC, Pietras RJ. Targeting aromatase and estrogen signaling in human non-small cell lung cancer. Ann N Y Acad Sci 2009; 1155: 194-205.

4 Burns TF, Stabile LP. Targeting the estrogen pathway for the treatment and prevention of lung cancer. Lung Cancer Manag 2014; 3: 43-52.

5 Baik CS, Eaton KD. Estrogen signaling in lung cancer: an opportunity for novel therapy. Cancers (Basel) 2012; 4: 969-88.

6 Siegfried JM. Women and lung cancer: does oestrogen play a role? Lancet Oncol 2001; 2: 506-13.

7 Hsu LH, Liu KJ, Tsai MF, Wu CR, Feng AC, Chu NM, et al. Estrogen adversely affects the prognosis of patients with lung adenocarcinoma. Cancer Sci 2015; 106: 51-9.

8 Shen H, Yuan Y, Sun J, Gao W, Shu YQ. Combined tamoxifen and gefitinib in non-small cell lung cancer shows antiproliferative effects. Biomed Pharmacother 2010; 64: 88-92.

9 Garon EB, Pietras RJ, Finn RS, Kamranpour N, Pitts S, MarquezGarban DC, et al. Antiestrogen fulvestrant enhances the antiproliferative effects of epidermal growth factor receptor inhibitors in human non-small-cell lung cancer. J Thorac Oncol 2013; 8: 270-8.

10 Shen L, Li Z, Shen S, Niu X, Yu Y, Li Z, et al. The synergistic effect of EGFR tyrosine kinase inhibitor gefitinib in combination with aromatase inhibitor anastrozole in non-small cell lung cancer cell lines. Lung Cancer 2012; 78: 193-200.

11 Pasqualini JR. Estrogen sulfotransferases in breast and endometrial cancers. Ann N Y Acad Sci 2009; 1155: 88-98.

12 Suzuki T, Nakata T, Miki Y, Kaneko C, Moriya T, Ishida T, et al. Estrogen sulfotransferase and steroid sulfatase in human breast carcinoma. Cancer Res 2003; 63: 2762-70.

$13 \mathrm{Fu} \mathrm{J}$, Weise AM, Falany JL, Falany CN, Thibodeau BJ, Miller FR, et al. Expression of estrogenicity genes in a lineage cell culture model of human breast cancer progression. Breast Cancer Res Treat 2010; 120: 35-45.
14 Zhang H, Varlamova O, Vargas FM, Falany CN, Leyh TS. Sulfuryl transfer: the catalytic mechanism of human estrogen sulfotransferase. J Biol Chem 1998; 273: 10888-92.

15 Ji XW, Chen GP, Song Y, Hua M, Wang LJ, Li L, et al. Intratumoral estrogen sulfotransferase induction contributes to the anti-breast cancer effects of the dithiocarbamate derivative TM208. Acta Pharmacol Sin 2015; 36: 1246-55.

16 Gong H, Jarzynka MJ, Cole TJ, Lee JH, Wada T, Zhang B, et al. Glucocorticoids antagonize estrogens by glucocorticoid receptormediated activation of estrogen sulfotransferase. Cancer Res 2008; 68: 7386-93.

17 Xu Y, Liu X, Guo F, Ning Y, Zhi X, Wang X, et al. Effect of estrogen sulfation by SULT1E1 and PAPSS on the development of estrogendependent cancers. Cancer Sci 2012; 103: 1000-9.

18 Herr I, Pfitzenmaier J. Glucocorticoid use in prostate cancer and other solid tumours: implications for effectiveness of cytotoxic treatment and metastases. Lancet Oncol 2006; 7: 425-30.

19 Wang H, Wang Y, Rayburn ER, Hill DL, Rinehart JJ, Zhang RW. Dexamethasone as a chemosensitizer for breast cancer chemotherapy: Potentiation of the antitumor activity of adriamycin, modulation of cytokine expression, and pharmacokinetics. Int J Oncol 2007; 30: $947-53$.

20 Sau S, Banerjee R. Cationic lipid-conjugated dexamethasone as a selective antitumor agent. Eur J Med Chem 2014; 83: 433-47.

21 Geng $\mathrm{Y}$, Wang J, Jing $\mathrm{H}$, Wang HW, Bao YX. Inhibitory effect of dexamethasone on Lewis mice lung cancer cells. Genet Mol Res 2014; 13: 6827-36.

22 Komiya A, Shimbo M, Suzuki H, Imamoto T, Kato T, Fukasawa S, et al. Oral low-dose dexamethasone for androgen-independent prostate cancer patients. Oncol Lett 2010; 1: 73-9.

23 Rhen T, Grissom S, Afshari C, Cidlowski JA. Dexamethasone blocks the rapid biological effects of 17 beta-estradiol in the rat uterus without antagonizing its global genomic actions. FASEB J 2003; 17 : 1849-70.

24 Zhou F, Bouillard B, Pharaboz-Joly MO, Andre J. Non-classical antiestrogenic actions of dexamethasone in variant MCF-7 human breast cancer cells in culture. Mol Cell Endocrinol 1989; 66: 189-97.

25 Vardy J, Chiew KS, Galica J, Pond GR, Tannock IF. Side effects associated with the use of dexamethasone for prophylaxis of delayed emesis after moderately emetogenic chemotherapy. Br J Cancer 2006; 94: 1011-5.

26 Ayroldi E, Macchiarulo A, Riccardi C. Targeting glucocorticoid side effects: selective glucocorticoid receptor modulator or glucocorticoidinduced leucine zipper? A perspective. FASEB J 2014; 28: 5055-70.

27 Vichai V, Kirtikara K. Sulforhodamine B colorimetric assay for cytotoxicity screening. Nat Protoc 2006; 1: 1112-6.

28 Cheng XL, Zhou TY, Li B, Li MY, Li L, Li ZQ, et al. Methotrexate and 5-aminoimidazole-4-carboxamide riboside exert synergistic anticancer action against human breast cancer and hepatocellular carcinoma. Acta Pharmacol Sin 2013; 34: 951-9.

29 Wang LQ, Falany CN, James MO. Triclosan as a substrate and inhibitor of 3'-phosphoadenosine 5'-phosphosulfate-sulfotransferase and UDPglucuronosyl transferase in human liver fractions. Drug Metab Dispos 2004; 32: 1162-9.

30 Zhou TY, Huang CQ, Chen Y, Xu JJ, Shanbhag PD, Chen GP. Methamphetamine regulation of sulfotransferase $1 \mathrm{~A} 1$ and $2 \mathrm{~A} 1$ expression in rat brain sections. Neurotoxicology 2013; 34: 212-8.

31 Shao X, Li J, Wang S, Chen G, Xu J, Ji X, et al. Exogenous dopamine induces dehydroepiandrosterone sulfotransferase (rSULT2A1) in rat liver and changes the pharmacokinetic profile of moxifloxacin in rats. Drug Metab Pharmacokinet 2015; 30: 97-104. 
32 Ko JC, Tsai MS, Weng SH, Kuo YH, Chiu YF, Lin YW. Curcumin enhances the mitomycin C-induced cytotoxicity via downregulation of MKK1/2-ERK1/2-mediated Rad51 expression in non-small cell lung cancer cells. Toxicol Appl Pharmacol 2011; 255: 327-38.

33 Houghton P, Fang R, Techatanawat I, Steventon G, Hylands PJ, Lee CC. The sulphorhodamine (SRB) assay and other approaches to testing plant extracts and derived compounds for activities related to reputed anticancer activity. Methods 2007; 42: 377-87.

34 Medlock KL, Forrester TM, Sheehan DM. Short-term effects of physiological and pharmacological doses of estradiol on estrogen receptor and uterine growth. J Recept Res 1991; 11: 743-56.

35 Moon EY, Ryu YK, Lee GH. Dexamethasone inhibits in vivo tumor growth by the alteration of bone marrow $\mathrm{CD} 11 \mathrm{~b}(+)$ myeloid cells. Int Immunopharmacol 2014; 21: 494-500.

36 Li M, Li Y, Yin Q, Mi R, Chen L, Du J, et al. Treatment with cyclophosphamide, vindesine, cytarabine, dexamethasone and bleomycin in patients with relapsed/refractory diffuse large B-cell lymphoma. Leuk Lymphoma 2014; 55: 1578-83.

37 Kumar VH, IM NN, Huilgol SV, Yendiger SM, H N, Ch R. Dose dependent hepatic and endothelial changes in rats treated with dexamethasone. J Clin Diagn Res 2015; 9: FF08-10.

38 Lother SA, Harding GA, Musto G, Navaratnam S, Pitz MW. Antiestrogen use and survival of women with non-small cell lung cancer in Manitoba, Canada. Horm Cancer 2013; 4: 270-6.

39 Hu R, Hilakivi-Clarke L, Clarke R. Molecular mechanisms of tamoxifenassociated endometrial cancer (Review). Oncol Lett 2015; 9: 1495501.

40 Stabile LP, Lyker JS, Gubish CT, Zhang W, Grandis JR, Siegfried JM. Combined targeting of the estrogen receptor and the epidermal growth factor receptor in non-small cell lung cancer shows enhanced antiproliferative effects. Cancer Res 2005; 65: 1459-70.
41 Xu R, Shen H, Guo R, Sun J, Gao W, Shu Y. Combine therapy of gefitinib and fulvestrant enhances antitumor effects on NSCLC cell lines with acquired resistance to gefitinib. Biomed Pharmacother 2012; 66: 384-9.

42 Ko JC, Chiu HC, Syu JJ, Jian YJ, Chen CY, Jian YT, et al. Tamoxifen enhances erlotinib-induced cytotoxicity through down-regulating AKTmediated thymidine phosphorylase expression in human non-smallcell lung cancer cells. Biochem Pharmacol 2014; 88: 119-27.

43 Johnson MD, Zuo H, Lee KH, Trebley JP, Rae JM, Weatherman RV, et al. Pharmacological characterization of 4-hydroxy-N-desmethyl tamoxifen, a novel active metabolite of tamoxifen. Breast Cancer Res Treat 2004; 85: 151-9.

44 Yuan Y, Zhou X, Ren Y, Zhou S, Wang L, Ji S, et al. Semi-mechanismbased pharmacokinetic/pharmacodynamic model for the combination use of dexamethasone and gemcitabine in breast cancer. J Pharm Sci 2015; 104: 4399-408.

45 Petrillo MG, Fettucciari K, Montuschi P, Ronchetti S, Cari L, Migliorati G, et al. Transcriptional regulation of kinases downstream of the $T$ cell receptor: another immunomodulatory mechanism of glucocorticoids. BMC Pharmacol Toxicol 2014; 15: 35.

46 Lee MJ, Lee KC, Kim HY, Lee WS, Seo WJ, Lee C. Comparison of ramosetron plus dexamethasone with ramosetron alone on postoperative nausea, vomiting, shivering and pain after thyroid surgery. Korean J Pain 2015; 28: 39-44.

47 Rutz HP. Effects of corticosteroid use on treatment of solid tumours. Lancet 2002; 360: 1969-70.

48 Egberts JH, Schniewind B, Pätzold M, Kettler B, Tepel J, Kalthoff H, et al. Dexamethasone reduces tumor recurrence and metastasis after pancreatic tumor resection in SCID mice. Cancer Biol Ther 2008; 7: 1044-50. 